\title{
Socio-economic determinants of production and consumption of African Indigenous Vegetables in Kakuma refugee camp and Kakuma town, Kenya.
}

\author{
Stephen Kahara ${ }^{1}$ Losenge Turoop $^{1}$ and Eucabeth Majiwa ${ }^{2}$ \\ ${ }^{1}$ Department of Horticulture and Food Security \\ ${ }^{2}$ Department of Agricultural and Resource Economics \\ ${ }^{1,2}$ School of Agriculture and Environmental Sciences, Jomo Kenyatta University of Agriculture and Technology, P.O Box 62000-
} 00200, Nairobi, Kenya.

Corresponding Author Email: kascat2050@gmail.com

DOI: 10.31364/SCIRJ/v9.i06.2021.P0621863

http://dx.doi.org/10.31364/SCIRJ/v9.i06.2021.P0621863

\begin{abstract}
African Indigenous Vegetables remain important in the food system due to their relative importance in providing nutritious food for the rural and urban population. AIVs contain high micronutrients such as carotene, iron, calcium, magnesium and vitamins important for proper body functioning hence contributing to food security and nutrition especially in resource-poor households. AIVs have low input requirements and can adapt to many agro-ecological zones. Despite their importance, the production and consumption of AIVs are progressively declining in Kenya. Further, AIVs remain less exploited, especially in the arid and semi-arid areas. It is on this backdrop that this study assessed the socio-economic determinants of production and utilization of AIVs in the Kakuma refugee camp and its environs. Using a descriptive survey design, the study collected data from 172 farmers from Kakuma Refugee Camp and Kakuma Town. Both descriptive and inferential statistical analyses were used to obtain frequencies, mean, chi-square test and a linear regression model to assess socio-economic determinants of production and consumption of AIVs. The results indicated that the main AIVs produced and consumed in Kakuma town and refugee camp were Amaranths, Cowpea and Jute mallow. The country of origin, marital status and age of the household head significantly influenced the production of AIVs. Further, land ownership, communal farming and awareness creation by self-help groups and preferences of AIVs to exotic vegetables had a significant relationship with the production and consumption of AIVs. Income generation was a motivating factor for producing AIVs. Since age and the country of origin influenced the production and consumption of AIVs, the study recommends that there is a need for people to adopt a culture of producing and consuming more AIVs to promote production of AIVs.
\end{abstract}

Key words: African Indigenous Vegetables (AIVs), production, consumption, Kakuma

\section{Introduction}

The role of Indigenous Vegetables in the food system is widely recognized due to their relative importance in providing nutritious food both in rural and urban areas (Muhanji et al., 2011; Ngugi et al., 2007). Indigenous Vegetables have secondarily originated from Africa and their natural habitat is in Sub-Saharan Africa (SSA) thus are often referred to as "African Indigenous Vegetables" (Schippers, 2002). AIVs are known to contain high micronutrients such as carotene, iron, calcium, magnesium and vitamins important for proper body functioning (Yuan et al., 2018). Since they have provided a delicate balance of food security and sustainable soil productivity, their production, trade and consumption are expanding in Africa. African indigenous vegetables have the potential of reducing food insecurity and malnutrition particularly for resource-poor households in SSA due to their ability to adapt to low inputs and high nutritional composition (Opiyo et al., 2015).

www.scirj.org

(C) 2021, Scientific Research Journal

http://dx.doi.org/10.31364/SCIRJ/v9.i06.2021.P0621863

This publication is licensed under Creative Commons Attribution CC BY. 
Current studies indicate AIVs are popularly consumed in almost all the countries of the Common Market for Eastern and Southern Africa (COMESA). The size of the AIV market in SSA remains substantial. Some of AIVs found across Eastern Africa include but are not limited to amaranth (Amaranthus spp), Cow pea (Vignaun guiculata), slenderleaf (Crotalaria spp), African nightshade (Solanum spp) and spider plant (Cleome gynandra). African Indigenous Vegetables have been in use for a prolonged period in Africa as they were introduced over a century ago and thus, they have become part of the food culture in Africa (Maundu, 1999). They form a major part of traditional diets of households and agricultural communities both in urban and the rural areas (Grubben and Denton, 2004) thus forming part of the household food security strategies for generations.

African indigenous vegetables are increasingly becoming popular due to their contribution in food and nutrition security to millions of Africans in rural, peri-urban and urban areas (Rubaihayo, 2002). Besides their nutritional importance, AIVs are also reported to have medicinal values with some believed to cure multiple illnesses (Kimiywe et al., 2007). For instance, amaranth is believed to cure malaria, colds and flu and diarrhoea while African nightshade is believed to cure malaria, high blood pressure and diabetes among others. Stinging nettle on the other hand is said to cure backache, anaemia, colds and coughs among the urban and peri-urban residents of Nairobi (Kimiywe et al., 2007). Also, AIVs are reported to have immune-boosting properties and those who are in dire need of boosting their immunity like the HIV infected and other vulnerable groups are fast adopting their use. Amaranths for example is one the most popular and highly nutritious leafy vegetable both in Africa and in Asia (Maughan et al., 2011). The health benefits credited to amaranth include decreasing plasma cholesterol levels, exerting an antitumor activity, reducing blood glucose levels and anaemia. It has the potential for significantly impacting on malnutrition (Maughan et al., 2011). Amaranths have excellent nutritional value because of their high content of essential micronutrients such as $\beta$-carotene, iron, calcium, vitamin $C$ and folic acid (Priya et al. 2007). Stoilova et al. (2014) noted that amaranth, African nightshade and spider plant protein content ranged from 3.2 to $4.4 \mathrm{~g}, \beta$-carotene from 2.7 to $5.8 \mathrm{mg}$, iron from 2.2 to $3.8 \mathrm{mg}$, calcium from 158 to $582 \mathrm{mg}$, and zinc from 0.5 to $1.5 \mathrm{mg} 100 \mathrm{~g}^{-1}$ of fresh weight.

Despite their higher nutritional and economic value, AIVs have faced a myriad of challenges. Some of the challenges that affect production and consumption of AIVs include low awareness of their nutrition potential, negative perception as poor man's crop, the seasonal nature of their production, poor quality seed, inadequate technical information on their production and poor marketing system among others (Abukustsa-Onyango, 2002). In Kenya, AIV market makes up less than 10\% of the marketed vegetable commodities (Abukutsa-Onyango et al., 2007) and most of the trading is conducted in the open-air or wet markets. Production and consumption of African IindigenousVegetables (AIVs) is progressively declining in Kenya (Namutebi et al., 2010) and this is attributed to diminishing role of AIVs in the traditional diets of communities (Gido, Bett and Bokelmann, 2016). Gido et al. (2016) points out that changing food habits, loss of indigenous knowledge, ignorance of the nutritional and health benefits associated with their consumption, seasonality of production and supply, limited post-harvest processing and utilization, and seed shortage have collectively contributed to this apparent denigration. The loss of indigenous knowledge, lack of information on potential nutraceutical benefits and changing food habits, have also progressively denigrated the dietary and economic importance of AIVs. Besides, there is a lack of proper infrastructure and institutions to be used for the implementation and sustainable production of these crops. In addition, AIVs have also been neglected for long by researchers, funding agencies and policy-makers (Abukutsa-Onyango et al., 2010). Due to these challenges, these vegetables are facing extinction yet the communities in the region continue to languish in malnutrition, food insecurity and poverty. This scenario is worsened especially in refugee camps which are characterized by high population, food insecurity and high malnutrition rates. This contributed to food insecurity and impoverished refugee communities.

www.sciri.org

(c) 2021, Scientific Research Journal

http://dx.doi.org/10.31364/SCIRJ/v9.i06.2021.P0621863

This publication is licensed under Creative Commons Attribution CC BY. 
Examining the existing literature indicates that a number of studies investigate the production of African Indigenous Vegetables. This includes but is not limited to studies conducted by Abukutsa et al., 2007; Abukutsa-Onyango et al., 2010; Maundu, 1999; Grubben and Denton, 2004; Oluoch et al., 2009; Namutebi et al, 2010; Shackleton et al., 2010; Mulaudzi, Oyekale \& Ndou, 2019 and Maundu et al., 1999. Other studies have looked at consumption of African Indigenous Vegetables such as the studies done by Vorster et al., 2007; Gido, Bett \& Bokelmann, 2016; Gido et al., 2016; Gido et al., 2017; Kimiywe et al.,2007; Tabuti et al., 2004; Abukutsa-Onyango et al., 2007 and Huang et al., 2002 among others. However, majority of the above studies focus on the productivity of AIVs as a function of a given technology, land size, use of inputs and agronomic practices in high or mid potential areas while ignoring the low potential areas. While the production of African Indigenous Vegetables remains important, its emphasis has been promoted more on high potential areas with the low potential areas being ignored. There is limited information concerning the production and consumption of AIVs, especially in the arid and semi-arid regions. The promotion of production, marketing and consumption of AIVs in arid and semi-arid areas remains rare. This study, therefore fills the above gap by assessing the socio-economic factors of AIV production and consumption in Kakuma refugee camp and Kakuma town using a field survey. Kakuma is used as a case study since Kakuma refugee camp is one of the largest refugee camps in East and Central Africa. Kakuma refugee camp hosts about 147,240 refugees (Turkana CIDP 2018-2022). It has a high potential for production of AIVs and consumption owing to its high population, high food insecurity and high malnutrition rates; however, AIVs full potential in terms of production and consumption Kakuma refugee camp and its environs is yet to be realized. This information is useful as it will help in boosting the production and consumption of AIVs in the study area.

\section{Problem Statement}

AIVs have overwhelming superiority in terms of nutritional value, food security, employment creation and healing traits among others. Despite their importance, AIVs have been neglected for many years by researchers, policy makers and funding agencies. As a result, their availability has declined with their production focusing majorly for subsistence use in home gardens, peri-urban and urban production systems in SSA (Oluoch et al., 2009). While the production remains important, its emphasis has been promoted more on high potential areas with the low potential being ignored.

Despite AIVs doing well even in relatively harsh climatic conditions, their production still remains low. The production of AIVs especially in the arid and semi-arid areas is low.AIVs are not widely grown in north-western region of Kenya. AIVs are not popularly grown particularly in Kakuma refugee camp and Kakuma town despite the area having a high potential for production of AIVs and consumption owing to its high population, high food insecurity and high malnutrition rates. AIVs full potential in terms of production and consumption is not fully exploited by the people in this region. So far, there is scanty information on production of AIVs in low potential areas with none of the studies on the various aspects of AIVs in semi-arid and arid regions of Kenya existing. Thus, there is urgent need to establish reasons why these vegetables are not widely grown in North-western region of Kenya, yet if grown it could impart positively to food security and nutritional situation in the region.

This study therefore fills the above gap by assessing the socio-economic factors of AIVs production and consumption in Kakuma refugee camp and Kakuma town using a field survey. This study is important since it provides useful insight to policy makers, producers and consumers of AIVs that is likely to help increasing the adoption of AIVs through their cultivation, utilization; conservation and commercialization. The study also provides useful information that will help in addressing the challenges of both food and nutritional security in Kakuma through cultivation of AIVs. The fact that AIVs are generally cheap and can survive in low potential areas,

www.scirj.org

(C) 2021, Scientific Research Journal

http://dx.doi.org/10.31364/SCIRJ/v9.i06.2021.P0621863

This publication is licensed under Creative Commons Attribution CC BY. 
recommendations from this study would also support populations in such areas in terms of subsistence and income generation, especially for the resource poor women and men farmers with low capital investments through incorporation of AIVs in their diets.

\section{Justification}

African Indigenous Vegetables have been shown to reduce and control micronutrient deficiencies and food insecurity in resource poor communities. Besides being micronutrient-rich, AIVs have the added advantage of possessing other desirable traits including their resistance to drought, pests and diseases, are quite acceptable to local tastes, are easy to grow and require fewer inputs and many often grow wild. Despite of their higher nutritional and economic value, AIVs have faced a myriad of challenges. Some of the challenges that affect production and consumption of AIVs include: low awareness of their nutrition potential, negative perception as poor man's crop, the seasonal nature of their production, poor quality seed, inadequate technical information on their production and poor marketing system among others (Abukutsa-Onyango, 2002). The production of AIVs in arid and semi-arid areas remains low despite AIVs having potential of surviving even in harsh climatic conditions. Therefore, there is an urgent need for intervention based on scientific knowledge to improve uptake of AIVs especially in arid and semi-arid areas.

This study provides a better understanding on the production and consumption of AIVs in arid and semi-areas using Kakuma refugee camp and Kakuma town as a case study. The findings provide useful insight to policy-makers and farmers which will help to improve the production and consumption of AIVs in the study area.

\section{Limitations of the Study}

Both Kakuma refugee camp and town are relatively large, therefore, obtaining a sample representative for the population was difficult. However, simple random sampling was used to select the sample from both the town and the camp. The other limitation was the high illiteracy levels in the study area. However, this was solved by the researcher through the use of research assistants who are experienced enumerators within the study area.

\section{Theoretical Review}

This study was guided by the Ecological Apparency Hypothesis forwarded by Feeny (1976). The ecological Apparency is an ethnobotanical theory that suggests that people in their natural lives will most likely collect and use apparent plants (the most easily found in the vegetation). According to the theory, the apparency of the plant species to herbivores was responsible for the patterns of defensive traits. Fenny observed that long -lived species were more likely to be apparent (bound to be found) and hence under strong selection. On the contrary, unapparent species were short lived and ephemeral in time and space and because of this unpredictability, it would be difficult for consumers to specialize on them. The theory observes that the apparency of some species of plants would determine if they were selected and consumed by herbivores or not, and that the herbivores in turn would determine which quantity and quality is optimum.

This theory was ideal for this study since the study is dealing with AIVs whose consumption in Kenya is on the downward trend and most importantly, the study was done in arid areas and more so in a refugee camp where the availability of plants and particularly the

www.scirj.org

(C) 2021, Scientific Research Journal

http://dx.doi.org/10.31364/SCIRJ/v9.i06.2021.P0621863

This publication is licensed under Creative Commons Attribution CC BY. 
AIVs is highly prohibited. The theory was therefore ideal in establishing the socio-economic factors that determine the production and consumption of the AIVs.

\section{Literature Review}

Examining the existing literature, some studies have examined the production and consumption of AIVs. Shackleton et al. (2010) investigated the production and trade in AIVs in the urban and peri-urban areas of Durban-South Africa. A three-phase approach was adopted using a questionnaire survey of 165 farmers and gardeners, a survey of markets, and a questionnaire survey of 55 retailers and vendors. The interview schedule was a standardised one from the broader multi-country IndigenoVeg Project (IndigenoVeg, n.d). The study noted that most households grew AIVs, and collected them from the wild, primarily for home consumption. Modal income from sale was approximately R30 per month per farmer. Most of the AIVs producers were middle-aged to elderly females, with limited education, who had more experience in cultivating AIVs. The main constraints to greater sales were deemed to be low market demand and adverse climate. The commonest AIVs grown were Pumpkin leaves, Taro and Amaranth. Most retailers of AIVs were found to be younger females who were more educated than the AIVs farmers and they viewed retailing as a full-time occupation.

Mulaudzi, Oyekale \& Ndou (2019) did a study on technical efficiency of AIVs production in Vhembe District of Limpopo Province, South Africa. Using questionnaires, the study collected data from 114 small holder AIV farmers. The data was analyzed using the CobbDouglas production function. The results revealed that the sum of elasticity of production was 0.407 , indicating a decreasing return to scale. The land variable was found to be the most important factor of production to increase productivity with a higher elasticity compared to other variable inputs. Farmers in Vhembe district were subjected to smaller land size which they utilize to grow different crops, AIVs included. The results demonstrated that indigenous vegetables had potential of higher yield which translates to high potential to generate higher household income.

A study that evaluated the production and harvesting systems for African indigenous vegetables by Oluoch et al. (2009) in Northern Tanzania noted that the main differentiating attributes for production systems in AIVs included location, size, proximity to homestead, commercial or subsistence, nature and quantity of inputs, and whether the crops are planted in mixed or pure stands. The study found that in the study area, approximately one third of AIVs were intercropped, while two-thirds were cultivated in pure stands, with 67 per cent of all plots using sowing rather than broadcasting methods.

Mbugua et al. (2009) carried out a study on African indigenous vegetables and farmer-preferences in Central Kenya. Using interviews of 374 farmers within fourteen groups. Data was collected and analyzed using qualitative and quantitative methods. The study revealed that there was decreasing trend in number of species used as indigenous vegetables with intensification of agriculture. Farmers identified production constraints which included lack of knowledge on the following aspects of AIVs: production practices, cooking methods, and utilization and preservation methods. The farmers also indicated that lack of seed, low yields, competition with some exotic vegetables especially the brassicas such as kales; and the fact that indigenous vegetables were regarded as weeds and as low value crops therefore fetching low market price as the other factors that affected AIVs preference by the farmers.

www.scirj.org

(C) 2021, Scientific Research Journal

http://dx.doi.org/10.31364/SCIRJ/v9.i06.2021.P0621863

This publication is licensed under Creative Commons Attribution CC BY. 
On consumption of AIVs, some literature indicates that their consumption is varied and based on ethnicity, socio-economic attributes and country of origin among other factors. For instance, in South Africa, the consumption trend of AIVs is highly variable and depends on factors such as degree of urbanization, poverty status, distance to fresh produce markets and season of the year (Vorster et al., 2007). Poor households have been found to consume AIVs much more than their wealthier counterparts (Gido et al., 2017). According to Kimiywe et al. (2007), ethnicity strongly influences households' choice and consumption of AIVs in Kenya. On the other hand, in Bulamogi county of Uganda, consumption of wild food was limited to periods of food shortages, casual encounters and as supplements to major food crops (Tabuti et al., 2004).

In Tanzania, Kimambo (2016) analyzed the factors that influenced producers, traders and consumers awareness of AIVs in Arusha Tanzania. The study used interviews, focus group discussions (FGDs) and structured questionnaires to collect data from 381 respondents. Generalized regression model was used to determine awareness of AIVs among the respondents. The study found that gender, number of years in schooling, age, household size and farm size were the major factors that contributed to awareness of the respondents in the production, trading and consumption of AIVs in the study area.

Similarly, Kimambo et al. (2018) carried out a study on factors influencing farmers' nutrition knowledge and intake of traditional African vegetables in Tanzania. Using a sample of 63 households in Arumeru district, the study employed standard and generalized Poison models to analyze the data. The study found that gender and age of the respondent, household size and AIVs farm size influenced farmers' nutrition knowledge. Other factors included annual household income, household size and market price of AIVs. Further, factor analysis results indicated that medicinal properties of traditional vegetables positively influenced farmers' intake of vegetables. The "health factor" accounted for $31.4 \%$ of the total variance in the principal components' analysis. 'Personal perception factor' accounted for $13.79 \%$ whereas 'personal taste factor' accounted for $12.71 \%$ of the total variance. The study concluded that rural farming households consume traditional vegetables majorly because of their health attributes.

Wemali (2014) assessed the contribution of cultivated African indigenous vegetables to agro-biodiversity conservation and community livelihood in Mumias sugar belt, Kenya. In particular, the study isolated and analyzed factors that promote cultivation and consumption of AIVs. With a sample of 392 households, the study used FGDs, interview, questionnaire and observation checklists to collect data and analyzed using Shannon-Weaver Diversity Index (SDI). Factor analysis results identified financial gains, diversification and household size to land-size ratio, availability of land and seeds, and vegetable sufficiency as factors responsible for cultivation of the AIVs in the study area. The study concluded that cultivation of AIVs conserved, sustained and improved biodiversity and household livelihood.

Kebede and \& Bokelmann (2017) investigated the socioeconomic factors determining AIV production practices in rural and peri-urban areas while focusing on the application of fertilizer. The study used interviews to collect data from 1232 producers of AIVs in both rural and peri-urban centres of Kenya. The study results indicated that gender, age and education level of the household, determined the production of AIVs. The study also identified household size, marital status of the household head, income level, asset index, involvement in off-farm activities and distance from the market as socio-economic factors that influenced production practices of AIVs in rural and peri-urban areas in Kenya.

On the other hand, Ndegwa (2016) sought to establish socio-economic factors influencing smallholder pumpkin production, consumption and marketing in eastern and central Kenya regions. Using a sample of 432 respondents including 260 pumpkin growing

www.scirj.org

(C) 2021, Scientific Research Journal

http://dx.doi.org/10.31364/SCIRJ/v9.i06.2021.P0621863

This publication is licensed under Creative Commons Attribution CC BY. 
households and 172 primary traders, the study used multiple regression and Tobit models to analyze the data. The study results identified age, gender and education level of household head, household size, and household income were the socio-economic factors that were responsible for cultivation of pumpkins in the study area. The study also observed that farmers' group membership, off-farm activities, land tenure, farm area under pumpkins greatly contributed to the likelihood of farmers cultivating pumpkins.

\section{Research Methodology}

\section{Research Design}

This study used descriptive survey research designs. Orodho and Kombo (2002) posits that descriptive statistics describe the distribution of and relationship among variables and it can be used when collecting information about people's attitudes, opinions, habits or any social issue. Therefore, descriptive survey was useful in establishing the socio-economic determinants of production and consumption of AIVs in the study area.

\section{Target Population}

The target population was AIVs farmers of Kakuma refugee camp and Kakuma Town. There are about 147,240 refugees in Kakuma refugee camp and around 31,962 inhabitants in Kakuma Town (Turkana CIDP 2018-2022). According to Action Africa Help International (AAH) there are about 300 AIVs farmers in the refugee camp who are engaged in farming of more than ten types of vegetables (AAH, 2018)

\section{Sampling Techniques and Sample size}

This study used stratified purposive sampling to select a sample from the 300 AIVs farmers in Kakuma refugee camp and Kakuma town. An equal sample was considered from the two study sites. Using Yamane's formulae sample size of the study was calculated as follows: $\mathrm{n}=\frac{N}{1+N\left(e^{2}\right)}$ where, $\mathrm{n}$ is the sample size, $\mathrm{N}$ is the population and $\mathrm{e}$ is the margin of error (taken to be $5 \%$ for this study).

Thus the sample of the study was calculated as follows:

$\mathrm{n}=\frac{300 \text { farmers }}{1+300\left(.05^{2}\right)}=171.43$

Therefore, the sample size was approximately 172 farmers.

A total of 172 respondents involved in production and consumption of AIVs in Kakuma were used in data collection with 86 of them from Kakuma refugee camp and 86 respondents from Kakuma town.

\section{Data analysis.}

Both descriptive and inferential statistical analysis were used. Under descriptive analysis frequencies, means and percentages for the various quantitative characters were computed. Under the inferential analysis, the study utilized both chi-square test of independence and regression modeling to assess socio-economic determinants of production and consumption of AIVS in Kakuma refugee camp and Kakuma town. The linear regression model was specified as follows:

Production model/consumption regression model; $Y_{i}=\beta_{0}+\beta_{1} X_{i 1}+\beta_{2} X_{i 2}+\beta_{3} X_{i 3}+\beta_{4} X_{i 4}+\beta_{5} X_{i 5}+\ldots \ldots \ldots . .+\beta_{p} X_{i p}+\varepsilon_{i}$ for each observation I $=1 \ldots . n$ where

$\mathrm{Y}_{\mathrm{i}}$ is the $\mathrm{i}^{\text {th }}$ observation of the dependent variable (production cost of AIVs/expenditure on AIVs consumed by households), www.scirj.org 
$\mathrm{X}_{\mathrm{ij}}$ is $\mathrm{i}^{\text {th }}$ observation of the $\mathrm{j}^{\text {th }}$ independent variable, $\mathrm{j}=1,2 \ldots \ldots \ldots \ldots \mathrm{p}$. the values $\beta_{\mathrm{j}}$ represents parameters to be estimated, and $\varepsilon_{\mathrm{i}}$ is the $\mathrm{i}^{\text {th }}$ independent identically distributed normal error.

Where $Y_{1}$ is production cost of AIVs

Expenditure used for Consumption of AIVs;

$\mathrm{X}_{1}$ is the gender of the farmer/consumer;

$\mathrm{X}_{2}$ is age 18 years category of the farmer/consumer;

$\mathrm{X}_{3}$ is age 19 -30 years category of the farmer/consumer;

$\mathrm{X}_{4}$ is age $31-50$ years category of the farmer/consumer;

$\mathrm{X}_{5}$ is age $51-60$ years category of the farmer/consumer

$\mathrm{X}_{6}$ is age 60 years + category of the farmer/consumer

$\mathrm{X}_{7}$ is marital status (married);

$\mathrm{X}_{8}$ is the marital status (others)

$\mathrm{X}_{9}$ if the country of origin is Sudan;

$\mathrm{X}_{10}$ if the country of origin is S. Sudan;

$\mathrm{X}_{11}$ if the Country of origin is Ethiopia;

$\mathrm{X}_{12}$ if the country of origin is Somalia;

$\mathrm{X}_{13}$ if the Country of origin is Uganda

$\mathrm{X}_{14}$ if the Country of origin is DR Congo;

$\mathrm{X}_{15}$ is the education level (No formal education);

$\mathrm{X}_{16}$ is the Level of education (KCPE);

$\mathrm{X}_{17}$ is the Level of education (KCSE) and

$\mathrm{X}_{18}$ is the Level of education (Tertiary)

A 95\% confidence level and a significance level $(\alpha)$ of 0.05 was assumed throughout the study.

\section{Results and Discussion}

\section{Demographic characteristics}

The results indicated that there were more male (62.3\%) participants compared to the female (37.7\%) in Kakuma refugee camp while in Kakuma town there was equal presentation of gender. Majority of the respondents were found to be within the age bracket of 51 to 60 years $(34.0 \%)$ while those who were more than 61 years comprised about $11.3 \%$ of the sample in Kakuma refugee camp. Those of middle age between $31-50$ years were $24.5 \%$, the young adults $19-30$ years were $22.6 \%$ while $7.5 \%$ were aged 18 years. In Kakuma town majority of the respondents were within the age bracket of 19-30 years (40.6\%), $31.3 \%$ and $18.8 \%$ of the respondents were between the age bracket of 31-50 and 51-60 respectively while minority of the respondents of 18 years and those above 61 years were both at $4.7 \%$ In Kakuma town.

This study also showed that the majority of the respondents in Kakuma refugee camp were married (54.7\%), 20.8\% were single, $15.1 \%$ had separated with their spouses while $9.4 \%$ were widowed. This was slightly different in Kakuma town where $46.9 \%$ of the respondents were found to be married, $26.6 \%$ single, $17.2 \%$ widowed and $9.4 \%$ separated.

www.sciri.org

(c) 2021, Scientific Research Journal

http://dx.doi.org/10.31364/SCIRJ/v9.i06.2021.P0621863

This publication is licensed under Creative Commons Attribution CC BY. 
The study results also indicated that majority of the respondents originated from South Sudan for both refugee camp (18.9\%) and 29.7 $\%$ for the town. This is followed by Sudan and Ethiopia both at $17.0 \%$ in the camp and $21.9 \%$ in town for Sudan and $17.0 \%$ for Ethiopia. The least were from Uganda (13.2\%) and DRC Congo (3.8\%) in the refugee camp and Burundi and DRC Congo at $3.1 \%$ and $0.0 \%$ respectively inKakuma town. Others came from Somalia as well.

The study reveals that education levels in the study area was still low with the majority of the people with either primary or no formal education. $16 \%$ of the respondents from the refugee camp and $12 \%$ of those in town and its environs had no formal education. Only $3 \%$ of the respondents in the refugee camp had a tertiary education while those with tertiary education from town and its environs were $9 \%$.

\section{Production and Consumption of AIVs}

This study sought to establish if AIVs were produced and consumed in the study area. Figure 1 shows the respondents' responses.

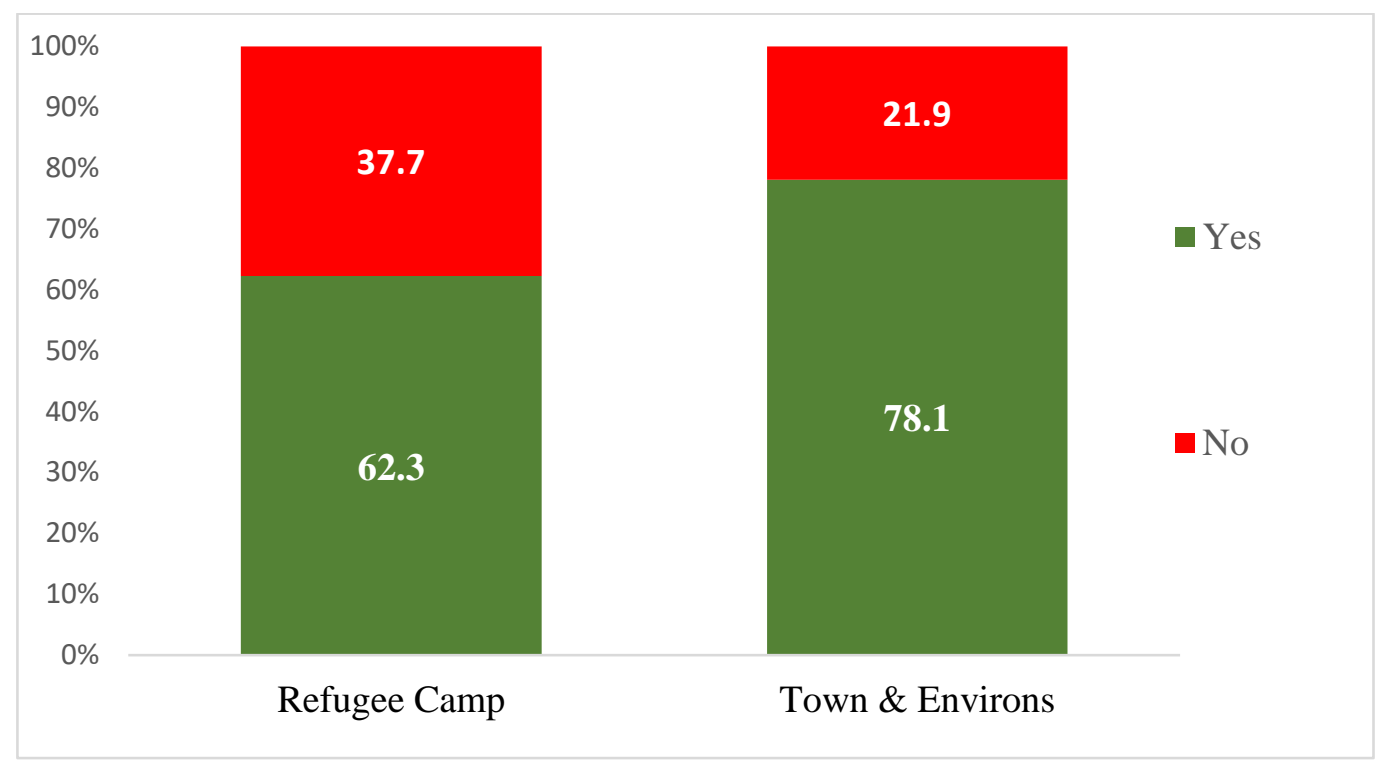

The results showed that $62.3 \%$ of the respondents from the refugee camp grew indigenous vegetables in their farms while $37.7 \%$ of the respondents did not plant indigenous vegetables in their farms. In Kakuma Town, 78.1\% of the respondents grew indigenous vegetables while only $21.9 \%$ did not. This indicates that most respondents from both the refugee camp and the town grew indigenous vegetables.

Examining the reasons for non-cultivation of AIVs by the respondents, Table 1 presents the results. The main reason for non-cultivation of AIVs $85 \%$ of the respondents in Kakuma refugee camp and $79 \%$ of the respondents in Kakuma town and its environs was due to water unavailability. Unfavorable weather was identified as the second major reason for non-cultivation of AIVs by $75 \%$ of the respondents in Kakuma refugee camp and $71 \%$ in Kakuma town. Pests and diseases was identified as the least factor for non-cultivation of AIVs. The study further revealed that soil fertility was seen a limiting factor to the growth of AIVs by only $7.1 \%$ of the respondents who did not grow in Kakuma town and its environs and $15 \%$ in the camp. On the size of land under AIVs, the study showed that $32 \%$ of the respondents in the refugee camp grew AIVs in less than a quarter (1/4) of an acre of land while 58\% of the respondents from town and its environs had less than a quarter ( $1 / 4)$ of an acre of land. The study also shows that $6 \%$ and $2 \%$ of the respondents had land area between $3 / 4$ - 1 acre in Kakuma refugee camp and Kakuma town and its environs respectfully. The study also showed that $34 \%$ of the response from the camp and $11 \%$ from town and the environs had between half and three-quarters of an acre. Thus, the study reveals

www.scirj.org 
that most of the respondents in the study area had small pieces of land under AIVs while none of the respondents had more than one acre under AIVs.

Table 1: Land Size under AIVs (acres) and reasons for non-cultivation of AIVs

\begin{tabular}{|c|c|c|c|c|c|}
\hline \multirow{2}{*}{ Variable } & \multirow{2}{*}{ 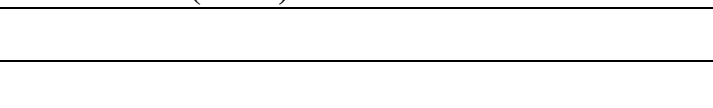 } & \multicolumn{2}{|c|}{ Refugee Camp } & \multicolumn{2}{|c|}{ Town and Environs } \\
\hline & & Freq & Percent & Freq & Percent \\
\hline \multirow{4}{*}{$\begin{array}{l}\text { Land size under } \\
\text { AIVs }\end{array}$} & Less than $1 / 4$ & 17 & 32.1 & 37 & 57.8 \\
\hline & $1 / 2-3 / 4$ & 18 & 34 & 7 & 10.9 \\
\hline & $3 / 4-1$ & 3 & 5.7 & 1 & 1.6 \\
\hline & Total & 33 & 100 & 50 & 100 \\
\hline \multirow{6}{*}{$\begin{array}{l}\text { Reason for non- } \\
\text { cultivation }\end{array}$} & Small pieces of land & 5 & 25.0 & 2 & 14.3 \\
\hline & Soil infertility & 3 & 15.0 & 1 & 7.1 \\
\hline & Pests and diseases & 1 & 5.0 & 2 & 14.3 \\
\hline & Change in tastes and preferences & 6 & 30.0 & 5 & 35.7 \\
\hline & Unfavourable weather & 15 & 75.0 & 10 & 71.4 \\
\hline & Lack of awareness campaigns & 7 & 35.0 & 2 & 14.3 \\
\hline
\end{tabular}

\section{Source: Field survey}

\section{Types of Indigenous Vegetables Produced}

This study established the type of AIVs grown in Kakuma refugee camp and town. Figure 2 shows the results. 


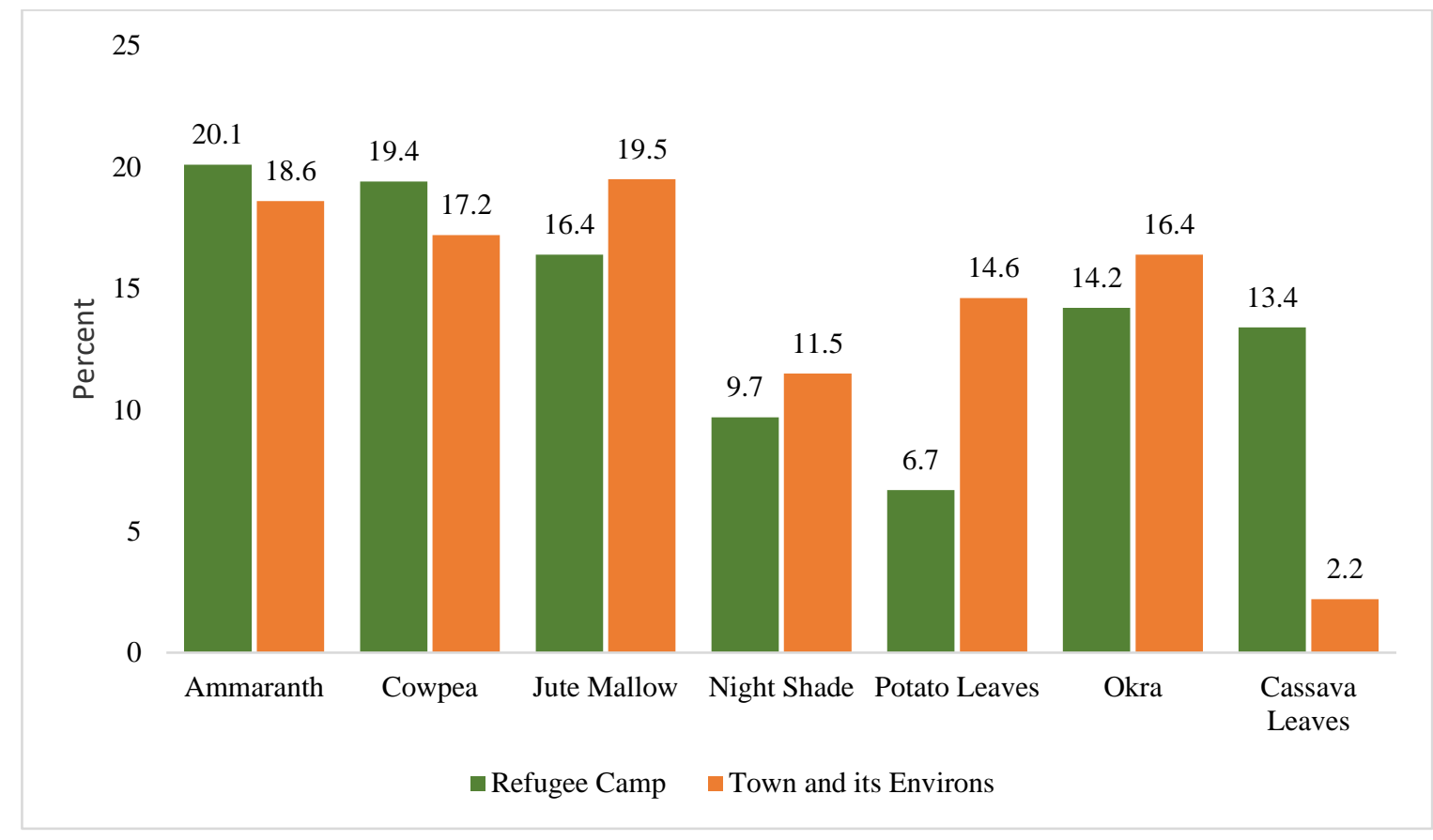

The study showed that the production of amaranths (20.1\%) and cowpeas $(19.4 \%)$ were higher in Kakuma refugee camp than in Kakuma town and its environs (18.6\%) and (17.2\%) respectively. However, jute mallow, black night shade, potato leaves and okra had the highest production in Kakuma town and its environs. The study indicates amaranth (20.1\%), cowpea (19.4\%), jute mallow (16.4\%), okra $(14.2 \%)$ and cassava (13.4\%) were the most produced AIVs in Kakuma refugee camp while jute mallow (19.5\%), amaranths (18.6\%), cowpea (17.2\%), Okra (16.4\%) and potato leaves (14.6\%) were the most produced AIVs in Kakuma town and its environs. The study also showed that potato leaves (6.7\%) and cassava leaves (2.2\%) were the least AIVs produced in Kakuma refugee camp and Kakuma town and its environs respectively. To determine the most and least produced indigenous vegetables in the study area, the study determined the average number of respondents growing the said AIVs. Table 2 shows the results.

Table 2: Indigenous Vegetables Produced (averages)

\begin{tabular}{lrrrrrrr}
\hline & Amaranth & Cowpea & $\begin{array}{r}\text { Jute } \\
\text { Mallow }\end{array}$ & $\begin{array}{r}\text { Night } \\
\text { shade }\end{array}$ & $\begin{array}{r}\text { Potato } \\
\text { leaves }\end{array}$ & Okra & $\begin{array}{r}\text { Cassava } \\
\text { leaves }\end{array}$ \\
\hline Camp (\%) & 20.1 & 19.4 & 16.4 & 9.7 & 6.7 & 14.2 & 13.4 \\
Town (\%) & 18.6 & 17.2 & 19.5 & 11.5 & 14.6 & 16.4 & 2.2 \\
Mean (\%) & $\mathbf{1 9 . 4}$ & $\mathbf{1 8 . 3}$ & $\mathbf{1 7 . 9}$ & $\mathbf{1 0 . 6}$ & $\mathbf{1 0 . 7}$ & $\mathbf{1 5 . 3}$ & $\mathbf{7 . 8}$ \\
\hline Rank & $\mathbf{1}$ & $\mathbf{2}$ & $\mathbf{3}$ & $\mathbf{6}$ & $\mathbf{5}$ & $\mathbf{4}$ & $\mathbf{7}$ \\
\hline
\end{tabular}

\section{Source: Field survey}

\section{Socio-demographic and economic Determinants of Production and Consumption of AIVs}

This study examined how the socio-demographic and economic characteristics of the respondents influenced production and consumption of AIVs in the study area. The factors considered were age, gender, marital status and education level for the demographic details. The study also established the influence of land ownership, production of AIVs in home countries, knowledge of AIVs, presence 
of self-help groups and associated activities, knowledge on AIVs, income generation enterprise and preferences of AIVs to exotic vegetables on production and consumption of AIVs in both Kakuma refugee camp and Kakuma town and its environs. Results are presented in table 3

Table 3: Influence of socio-economic factors on production and consumption of AIVs

\begin{tabular}{|c|c|c|c|c|c|c|c|}
\hline \multicolumn{8}{|c|}{ Production and Consumption of AIVs } \\
\hline & & & \multicolumn{2}{|c|}{ Refugee Camp } & \multicolumn{2}{|c|}{ Town and Environs } & \multirow[b]{2}{*}{ Total } \\
\hline & & & Yes & No & Yes & No & \\
\hline \multirow{10}{*}{$\begin{array}{l}\text { Age of Respondents } \\
\text { (years) }\end{array}$} & \multirow[t]{2}{*}{18} & Freq & 1 & 3 & 1 & 2 & 7 \\
\hline & & $\%$ & 14.3 & 42.9 & 14.3 & 28.6 & 100 \\
\hline & \multirow[t]{2}{*}{$19-30$} & Freq & 4 & 8 & 17 & 9 & 38 \\
\hline & & $\%$ & 10.5 & 21.1 & 44.7 & 23.7 & 100 \\
\hline & \multirow[t]{2}{*}{$31-50$} & Freq & 9 & 4 & 18 & 2 & 33 \\
\hline & & $\%$ & 27.3 & 12.1 & 54.5 & 6.1 & 100 \\
\hline & \multirow[t]{2}{*}{$51-60$} & Freq & 14 & 4 & 11 & 1 & 30 \\
\hline & & $\%$ & 46.7 & 13.3 & 36.7 & 3.3 & 100 \\
\hline & \multirow[t]{2}{*}{ Above 60} & Freq & 5 & 1 & 3 & 0 & 9 \\
\hline & & $\%$ & 55.6 & 11.1 & 33.3 & 0 & 100 \\
\hline \multirow[t]{4}{*}{ Gender } & \multirow[t]{2}{*}{ Male } & Freq & 15 & 18 & 23 & 9 & 65 \\
\hline & & $\%$ & 23.1 & 27.7 & 35.4 & 13.8 & 100 \\
\hline & \multirow[t]{2}{*}{ Female } & Freq & 18 & 2 & 27 & 5 & 52 \\
\hline & & $\%$ & 34.6 & 3.8 & 51.9 & 9.6 & 100 \\
\hline \multirow[t]{8}{*}{ Marital status } & \multirow[t]{2}{*}{ Married } & Freq & 21 & 8 & 28 & 2 & 59 \\
\hline & & $\%$ & 35.6 & 13.6 & 47.5 & 3.4 & 100 \\
\hline & \multirow[t]{2}{*}{ Single } & Freq & 4 & 7 & 8 & 9 & 28 \\
\hline & & $\%$ & 14.3 & 25 & 28.6 & 32.1 & 100 \\
\hline & \multirow[t]{2}{*}{ Windowed } & Freq & 3 & 2 & 9 & 2 & 16 \\
\hline & & $\%$ & 18.8 & 12.5 & 56.3 & 12.5 & 100 \\
\hline & \multirow[t]{2}{*}{ Separated } & Freq & 5 & 3 & 5 & 1 & 14 \\
\hline & & $\%$ & 35.7 & 21.4 & 35.7 & 7.1 & 100 \\
\hline \multirow{9}{*}{$\begin{array}{l}\text { Highest Education } \\
\text { Level }\end{array}$} & No formal & & & & & & \\
\hline & \multirow[t]{2}{*}{ Education } & Freq & 11 & 5 & 12 & 0 & 28 \\
\hline & & $\%$ & 39.3 & 17.9 & 42.9 & 0 & 100 \\
\hline & \multirow[t]{2}{*}{ KCPE } & Freq & 17 & 6 & 26 & 1 & 50 \\
\hline & & $\%$ & 34 & 12 & 52 & 2 & 100 \\
\hline & \multirow[t]{2}{*}{ KCSE } & Freq & 4 & 7 & 8 & 8 & 27 \\
\hline & & $\%$ & 14.8 & 25.9 & 29.6 & 29.6 & 100 \\
\hline & \multirow[t]{2}{*}{ Tertiary } & Freq & 1 & 2 & 4 & 5 & 12 \\
\hline & & $\%$ & 8.3 & 16.7 & 33.3 & 41.7 & 100 \\
\hline
\end{tabular}

$43 \%$ of the respondents who were 18 years in the refugee camp did not produce AIVs while $57 \%$ of those above 60 years in the same area produced and consumed AIVs. The study also shows that while $33 \%$ of the respondents above 60 years in town and its environs

www.scirj.org

(C) 2021, Scientific Research Journal http://dx.doi.org/10.31364/SCIRJ/v9.i06.2021.P0621863

This publication is licensed under Creative Commons Attribution CC BY. 
planted vegetables, only $14 \%$ of those who were 18 years planted vegetables in town and its environs. The results indicate that older people who were more likely to produce and consume AIVs than their younger counterparts. There more (52\% and 35\%) female growers and consumers of AIVs than males in town and its environs and the refugee camp respectively. The study indicates that females were more likely to produce and consume AIVs than their male counterparts.

In the refugee camp, $39 \%$ of the respondents with no formal education produced and consumed AIVs and $34 \%$ of those with primary school certificate (KCPE) did. However, the study reveals that there were few respondents with secondary school and tertiary education who produced and consumed AIVs in the refugee camp. In town and its environs, the study indicates that while $33 \%$ of those with tertiary education produced AIVs, $42 \%$ of them did not. $56 \%$ of the widowed respondents in town and its environs produced and consumed AIVs. Also, in town, $48 \%$ of the married people produced and consumed AIVs. The study also shows that the majority of the respondents who were single in the refugee camp and in town ( $25 \%$ and $32 \%$ respectively) did not produce or consume AIVs. 
Table 4 : Regression analysis of demographic factors and production and consumption of AIVs in Kakuma refugee camp and in Kakuma town and its environs

\begin{tabular}{|c|c|c|c|c|c|}
\hline & & Kakuma Refugee camp & & Kakuma Town & \\
\hline & & Production & Consumption & Production & Consumptio \\
\hline & & $0.508(0.693)$ & $3.778 * * *(0.003)$ & $2.761 * * *(<0.001)$ & $4.880 * * *(<0.001$ \\
\hline (Male $=1$; & male $=0$ ) & $0.316(0.383)$ & $0.0326(0.813)$ & $-0.294(0.183)$ & $-.486(0.235$ \\
\hline ars) & 18 & $0.102(0.568)$ & $.089(0.601)$ & $-0.284 * * *(0.012)$ & $-.289(0.153$ \\
\hline & $19-30$ & $0.063(0.441)$ & $0.325(.172)$ & $0.675(0.612)$ & $0.781(.309$ \\
\hline & $31-50$ & $0.727(.152)$ & $0.644 * * *(.009)$ & $0.675(.217)$ & $-.573(.320$ \\
\hline & $51-60$ & $0.809 * *(.042)$ & $0.328(.562)$ & $0.445(.110)$ & $-.673 *(.081$ \\
\hline & $60+$ & $0.769(.118)$ & $0.712(.079)$ & $0.398 * *(.028)$ & $0.551(0.211$ \\
\hline Status & Married & $0.026(0.721)$ & $-1.624(0.097)$ & $0.088(0.688)$ & $.145(0.717$ \\
\hline & Others & $0.339(0.518)$ & $-1.412(0.120)$ & $0.117 * *(.031)$ & $-.723(0.421$ \\
\hline of origin & Sudan & $.762(0.215)$ & $.606(0.299)$ & $-.306(0.228)$ & $-.749(0.109$ \\
\hline & S-Sudan & $.508(0.386)$ & $.031(0.955)$ & - & \\
\hline & Ethiopia & $1.203 * *(0.033)$ & $1.084(0.079)$ & $-.356(0.161)$ & $-.487(0.292$ \\
\hline & Somalia & $0.442(0.505)$ & $.993(0.121)$ & $.139(0.601)$ & $-.466(0.337$ \\
\hline & Uganda & $1.781 * * *(0.017)$ & $1.062(0.125)$ & $.101(0.702)$ & $-.988 * *(0.045$ \\
\hline & DR Congo & $0.882(0.343)$ & $.239(0.786)$ & $1.163 * *(0.025)$ & $.402(0.663$ \\
\hline of & No formal education & $0.533(0.989)$ & $-1.199(0.182)$ & $.074(0.554)$ & $.145(0.717$ \\
\hline$n$ & KCPE & $0.734(0.234)$ & $-1.901(0.147)$ & $.723(0.4430$ & $.0141(0.879$ \\
\hline & KCSE & $1.602(0.120)$ & $-.331(0.600)$ & $.288(0.317)$ & $.353(0.500$ \\
\hline & Tertiary & $-1.019(0.401)$ & $-1.810(0.162)$ & $-.080(0.804)$ & $-.255(0.664$ \\
\hline & $\mathbf{R}^{2}$ & 0.355 & 0.262 & 0.328 & 0.15 \\
\hline & $F(p$-value $)$ & $1.418(0.187)$ & $1.181(0.320)$ & $2.584 * * *(0.007)$ & $1.220(0.473$ \\
\hline
\end{tabular}

Note: ***,**,* indicates significance at $1 \%, 5 \%$ and $10 \%$ respectively 
Two models were run, one on production for both study areas i.e. Kakuma refugee camp and Kakuma town and its environs. The other model was on consumption of AIVs in Kakuma refugee camp and Kakuma town and its environs. The model regressions were presented as follows;

\section{Kakuma Refugee Camp}

\section{Production model}

$\mathrm{Y}_{\mathrm{i}}=0.508+0.316 \mathrm{X}_{1}+0.102 \mathrm{X}_{2}+0.063 \mathrm{X}_{3}+0.727 \mathrm{X}_{4}+0.809 \mathrm{X}_{5}+0.769 \mathrm{X}_{6}+0.026 \mathrm{X}_{7}+0.339 \mathrm{X}_{8}+0.762 \mathrm{X}_{9}+0.508 \mathrm{X}_{10}+1.203 \mathrm{X}_{11}+$ $0.442 \mathrm{X}_{12}+1.781 \mathrm{X}_{13}+0.882 \mathrm{X}_{14}+0.553 \mathrm{X}_{15}+0.734 \mathrm{X}_{16}+1.602 \mathrm{X}_{17}-1.019 \mathrm{X}_{18}$

\section{Consumption model}

$\mathrm{Y}_{\mathrm{i}}=3.778+0.0326 \mathrm{X}_{1}+0.089 \mathrm{X}_{2}+0.325 \mathrm{X}_{3}+0.644 \mathrm{X}_{4}+328 \mathrm{X}_{5}+0.712 \mathrm{X}_{6}-1.624 \mathrm{X}_{7}-1.412 \mathrm{X}_{8}+0.606 \mathrm{X}_{9}+$ $031 \mathrm{X}_{10}+1.084 \mathrm{X}_{11}+0.993 \mathrm{X}_{12}+1.062 \mathrm{X}_{13}+0.239 \mathrm{X}_{14}-1.199 \mathrm{X}_{15}-1.901 \mathrm{X}_{16}-1.331 \mathrm{X}_{17}-1.810 \mathrm{X}_{18}$

\section{Kakuma town and its environs}

\section{Production model}

$Y_{i}=2.761-0.297 X_{1}-0.284 X_{2}+675 X_{3}+0.675 X_{4}+0.445 X_{5}+0.398 X_{6}+0.088 X_{7}+0.117 X_{8}-0.306 X_{9}-0.356 X_{11}+0.139 X_{12}$ $+0.101 \mathrm{X}_{13}+1.163 \mathrm{X}_{14}+0.074 \mathrm{X}_{15}+0.723 \mathrm{X}_{16}+0.288 \mathrm{X}_{17}-0.080 \mathrm{X}_{18}$

\section{Consumption model}

$\mathrm{Y}_{\mathrm{i}}=4.880-0.486 \mathrm{X}_{1}-0.286 \mathrm{X}_{2}+0.781 \mathrm{X}_{3}-0.573 \mathrm{X}_{4}-0.673 \mathrm{X}_{5}+0.551 \mathrm{X}_{6}+0.145 \mathrm{X}_{7}-0.723 \mathrm{X}_{8}-0.749 \mathrm{X}_{9-}-0.487 \mathrm{X}_{11}-0.466 \mathrm{X}_{12}-$ $0.988 \mathrm{X}_{13}+0.402 \mathrm{X}_{14}+0.145 \mathrm{X}_{15}+0.014 \mathrm{X}_{16}+0.353 \mathrm{X}_{17}-0.255 \mathrm{X}_{18}$

In the first model, $35.5 \%\left(\mathrm{R}^{2}=0.355\right)$ variation in production of AIVs in Kakuma refugee camp was explained by the demographic factors of gender, age of the household head, marital status, country of origin and education level of the respondents. Of all the factors, the variable for the age between 51 and 60 years old and the participants whose country of origin was Ethiopia and Uganda, the variables were found to be statistically significant ( $\mathrm{p}$-value $=0.042,0.033$ and 0.017 respectively). This means that there was a high likelihood of older people to practice production and consumption of AIVs than their younger counterparts. It is also noted that Ethiopia and Uganda as the country of origin had a higher likelihood of involvement in production and consumption of AIVs. These results corroborates those of Kimambo (2016) who found that age was a major factor that contributed to awareness of the respondents in the production, trading and consumption of AIVs in the study area and Kimambo et al. (2018) who found that age of the respondent influenced farmers' nutrition knowledge. These study results also agree with those of Asfaw (1997) who noted that AIVs in Ethiopia dates back to ancient times and they are produced and consumed in considerable quantities to date. However, the overall model was statistically insignificant in predicting AIVs production $(\mathrm{F}=1.443, p=0.187)$.

The second model was on AIVs consumption in Kakuma refugee camp. The results showed that 26.2\% $\left(\mathrm{R}^{2}=0.262\right)$ variation in consumption of AIVs in Kakuma refugee camp was explained by the demographic factors of gender, age of the household head, marital status, level of education and country of origin. Of all the factors, age at 31 -50 years and marital status (Marr ied)were found to be statistically significant ( $p$-value $=0.009$ and 0.097 ) respectively. This means that age $31-50$ corresponded to the age when most respondents consumed AIVs in Kakuma. Among rural and urban dwellers in Kenya, Gido et al (2017) found that age, among other socio-economic factors significantly influenced consumption intensity of leafy AIVs. However, the overall model was found to be statistically insignificant in predicting AIVs consumption $(\mathrm{F}=1.181, p=0.329)$. 
The results of the third model showed that $32.8 \%\left(\mathrm{R}^{2}=0.328\right)$ variation in production of AIVs in Kakuma town and its environs was explained by the demographic factors of gender, age of the household head, marital status, level of education and country of origin. Of all the factors, age at 18 years and above 60 years, DRC as the country of origin and marital status (others) were found to be statistically significant (p-value $=0.012,0.028,0.025$ and 0.031 ) respectively. Bua \& Onang (2017) noted that the majority of the respondents were married compared to the singles indicating that AIVs are mainly food for the older people in the community as opposed to the younger generations. Vorster and Jansen Van Rensburg (2005) reported that the younger generations dislike vegetables because of the bitter taste, non-attractiveness and unpalatability. The overall model was statistically significant in predicting AIVs production $(\mathrm{F}=2.584, p=0.007)$.

The last model was on AIVs consumption in Kakuma town and its environs. The results showed that $15.2 \%\left(\mathrm{R}^{2}=0.152\right)$ variation in consumption of AIVs in Kakuma town was explained by the demographic factors of gender, age of the household head, marital status ,level of education and country of origin. Of all the factors, being from Uganda had a significant effect on AIV consumption at Kakuma town. These results reveals that having come from Uganda had a negative effect on production of AIVs. However, despite a significant effect, the relationship (coefficient) was negative (-.988) revealing a negative significant relationship between Uganda as country of origin and AIVs consumption in Kakuma town and its environs. However, the overall model was found to be statistically insignificant in predicting AIVs consumption $(\mathrm{F}=1.22, p=0.473)$.

\section{Chi-square results on Influence of socio-economic factors on production and cconsumption of AIVs}

Table 5 shows the chi square analysis for the relationship between socio-economic factors and production and consumption of AIVs. The results indicate that the age of respondents (18 years), (51-60 years) and 60 years and above had a significant relationship with production and consumption of AIVs at p-values; 0.028, 0.002 and 0.011 respectively. The study also indicate that marital status (other) had a positive significant relationship with production and consumption of AIVS in Kakuma town and its environs $\left(x^{2}=4.218, \mathrm{p}\right.$-value $\left.=0.019\right)$. Further, there was a statistically significant relationship between country of origin - Ethiopia $\left(x^{2}=0.092\right.$, p-value $=0.046, \phi=0.009)$, Uganda $\left(x^{2}=3.089\right.$, p-value $\left.=0.008, \phi=0.420\right)$ and production and consumption of AIVs in Kakuma town and its environs. It is however noted that in Uganda, while the regression model showed a negative coefficient (negative relationship), the chi-square test showed a positive significant relationship between both Ethiopia and Uganda as regards to production and consumption of AIVs. This implies that the country of origin had an effect on the likelihood of respondents producing and consuming AIVs. These results corroborate the findings of Kimambo (2016) who found that number of years in schooling, age, household size and farm size were the major factors that contributed to awareness in the production, trading and consumption of AIVs in Arusha, Tanzania. The study findings also agree with Ndegwa (2016) who identified that age, education level of household head, household size and household income were the socio-economic factors influencing production, consumption and marketing of pumpkins in eastern and central Kenya regions. Similarly, Kebede and Bokelmann (2017) using evidence from the HORTINLEA survey in Kenya, they studied African indigenous vegetables and their production practices in both rural and peri-urban centres of Kenya indicated that age and education level of the household, determined the production of AIVs in Kenya.

There was a significant relationship between the land ownership among the respondents and production and consumption of AIVs $\left(x^{2}=11.911, p=.023, \phi=.403\right)$. This implies that land was a key determinant in AIVs production since those with little pieces of 
land were more likely to grow other food crops besides AIVs. Those who did not own any land were limited in AIVs production.

Hence, owning land increased the likelihood of producing AIVs. Communal farming done by self-help groups $\left(x^{2}=56.121, p=\right.$ $0.040, \phi=0.258)$, creation of awareness by self-help groups $\left(x^{2}=8.243, p=0.002, \phi=0.202\right.$ and preferences for AIVs to exotic vegetables $\left(x^{2}=0.665, p=0.009, \phi=0.292\right)$ had a significant relationship with production and consumption of AIVs. This reveals that people who preferred AIVs to exotic vegetables had a higher likelihood of producing and consuming AIVs than those who preferred exotic vegetables. These findings agree with Wemali (2014) who found that financial gains, diversification, household size to land-size ratio, availability of land and seeds, and vegetable sufficiency as factors responsible for cultivation of the AIVs in Mumias sugar belt, Kenya. They also agree with Kimambo et al. (2018) who showed that among other socio-economic factors, AIVs farm size influenced farmers' nutrition knowledge in Arumeru district of Tanzania. Cultivation of AIVs in home countries and knowledge on AIVs had no significant relationship with production and consumption of AIVs.

Another reason for growing AIVs that had a significant relationship with production and consumption of AIVs was for income generation $\left(\mathrm{x}^{2}=21.733, \mathrm{p}=0.008, \phi=0.465\right)$. Cash received from sales of AIVs was significant; sh. 2001 to $3000\left(\mathrm{x}^{2}=69.412, \mathrm{p}=\right.$ $0.032, \phi=0.227)$ and sh. 3001 to $4000\left(\mathrm{x}^{2}=24.166, \mathrm{p}=0.001, \phi=0.338\right)$; and monthly expenditure of less than sh. 500 on AIVs $\left(x^{2}=2.565, p=0.026, \phi=0.298\right)$. These clearly indicates that most of the respondents produced and consumed AIVs because of its financial benefits. Those who spend less on AIVs were more likely to be involved in production and consumption of AIVs showing that they consumed from their production hence spent less on the same. 
Table 5: Chi square analysis for the relationship between socio-economic factors and production and consumption of AIVs

\begin{tabular}{|c|c|c|c|c|c|c|}
\hline Factor & & $\begin{array}{l}\text { Refugee } \\
\text { camp }\end{array}$ & $\begin{array}{c}\text { Town and } \\
\text { environs }\end{array}$ & $\begin{array}{c}\text { Chi-square } \\
\left(\mathbf{x}^{2}\right)\end{array}$ & $\begin{array}{l}\text { Asymptotic } \\
\text { significance }\end{array}$ & $\begin{array}{l}\text { Effect size } \\
(\phi)\end{array}$ \\
\hline \multirow[t]{2}{*}{ Gender } & Male & $33(62.3)$ & $32(50)$ & 9.331 & 0.099 & 0.322 \\
\hline & Female & $20(37.7)$ & $32(50)$ & 28.010 & 0.628 & 0.783 \\
\hline \multirow[t]{5}{*}{ Age (years) } & 18 & $4(7.5)$ & $3(4.7)$ & 0.762 & $* 0.028$ & 0.672 \\
\hline & $19-30$ & $12(22.6)$ & $26(40.6)$ & 57.120 & 0.471 & 0.223 \\
\hline & $31-50$ & $13(24.5)$ & $20(31.3)$ & 2.119 & 0.7882 & 0.185 \\
\hline & $51-60$ & $18(34.0)$ & $12(18.8)$ & 1.002 & $* 0.002$ & 0.601 \\
\hline & $60+$ & $6(11.3)$ & $3(4.7)$ & 11.272 & $* 0.011$ & 0.191 \\
\hline \multirow[t]{2}{*}{ Marital Status } & Married & $29(54.7)$ & $30(46.9)$ & 1.679 & 0.856 & 0.447 \\
\hline & Others & $24(45.3)$ & $34(53.1)$ & 4.218 & $* 0.019$ & 0.239 \\
\hline \multirow[t]{7}{*}{ Country of origin } & Sudan & $9(17)$ & $14(21.9)$ & 51.200 & 0.889 & 0.811 \\
\hline & S-Sudan & $10(18.9)$ & $19(29.7)$ & 26.998 & 0.692 & 0.483 \\
\hline & Ethiopia & $9(17)$ & $11(17.2)$ & 0.092 & $* 0.046$ & 0.900 \\
\hline & Somalia & $8(15.1)$ & $9(14.1)$ & 9.672 & 0.281 & 0.129 \\
\hline & Uganda & $7(13.2)$ & $9(14.1)$ & 3.089 & $* 0.008$ & 0.420 \\
\hline & Burundi & $8(15.1)$ & $0(0.0)$ & 7.100 & 0.809 & 0.337 \\
\hline & DR Congo & $2(3.8)$ & $2(3.1)$ & 0.329 & 0.073 & 0.545 \\
\hline \multirow[t]{4}{*}{ Level of education } & No formal education & $16(30.2)$ & $12(18.8)$ & 21.115 & 0.929 & 0.338 \\
\hline & $\mathrm{KCPE}$ & $23(43.4)$ & $27(42.2)$ & 67.772 & 0.894 & 0.176 \\
\hline & KCSE & $11(20.8)$ & $16(25.0)$ & 20.719 & 0.658 & 0.619 \\
\hline & Tertiary & $3(5.7)$ & $9(14.1)$ & 13.902 & 0.888 & 0.492 \\
\hline \multirow[t]{2}{*}{ Land ownership } & Yes & $32(60.0)$ & $45(70.0)$ & 11.911 & $* 0.023$ & 0.403 \\
\hline & No & $21(40.0)$ & $19(10.0)$ & 3.44 & 0.738 & 0.302 \\
\hline \multirow[t]{2}{*}{ Production of AIVs in home countries } & Yes & $38(71.7)$ & $33(51.6)$ & 52.003 & 0.224 & 0.092 \\
\hline & No & $15(28.3)$ & $31(48.4)$ & 4.905 & 0.54 & 0.322 \\
\hline \multirow[t]{2}{*}{ Knowledge on AIVs } & Yes & $33(62.2)$ & $48(75.0)$ & 1.779 & 0.908 & 0.117 \\
\hline & No & $20(37.8)$ & $16(25.0)$ & 23.003 & 0.427 & 0.078 \\
\hline Presence of self-help group & Yes & $39(73.6)$ & $41(64.1)$ & 7.441 & 0.891 & 0.298 \\
\hline
\end{tabular}




\section{Activities by self-help groups}

\section{Preference of AIVs to exotic vegetables}

Income generation

Reasons for cultivation of AIVs

Cash received from sales of AIVs

\section{Monthly expenditure on AIVs}

No

Communal farming

Communal trading

Awareness creation on farming

Yes

No

For food

Affordability

Medicinal value

$<1000$

$1001-2000$

$2001-3000$

$3001-4000$

$>5000$

$<500$

501- 1000

$1001-1500$

$1501-2000$

$>2000$

\begin{tabular}{rrrrr}
$14(26.4)$ & $23(35.9)$ & 10.33 & 0.078 & 0.37 \\
$33(62.2) \#$ & $39(31.3) \#$ & 56.121 & $* 0.040$ & 0.258 \\
$26(49.1) \#$ & $20(31.3) \#$ & 1.332 & 0.669 & 0.365 \\
$43(81.1) \#$ & $42(65.3) \#$ & 8.243 & $* 0.002$ & 0.202 \\
$31(57.4)$ & $34(53.1)$ & 0.665 & $* 0.009$ & 0.292 \\
$22(42.6)$ & $30(46.9)$ & 9.001 & 0.328 & 0.41 \\
$44(83.0)$ & $41(64.1)$ & 21.733 & $* 0.008$ & 0.465 \\
$42(79.2)$ & $54(84.4)$ & 4.009 & 0.437 & 0.092 \\
$24(43.3)$ & $33(51.6)$ & 6.34 & 0.229 & 0.322 \\
$39(73.6)$ & $21(32.8)$ & 0.775 & .983 & 0.438 \\
$22(41.5)$ & $30(46.9)$ & 48.121 & 0.453 & 0.117 \\
$18(34.0)$ & $29(45.3)$ & 7.001 & 0.087 & 0.078 \\
$4(7.5)$ & $3(4.9)$ & 69.412 & $* 0.032$ & 0.227 \\
$7(13.2)$ & $2(2.1)$ & 24.166 & $* 0.001$ & 0.338 \\
$2(3.8)$ & 0 & 1.908 & 0.065 & 0.21 \\
$4(7.5)$ & $4(6.3)$ & 2.565 & $* 0.026$ & 0.298 \\
$12(22.6)$ & $18(28.1)$ & 8.009 & 0.065 & 0.37 \\
$18(34.0)$ & $21(32.8)$ & 4.786 & 0.393 & 0.41 \\
$14(26.4)$ & $9(14.1)$ & 9.225 & 0.324 & 0.126 \\
$5(9.4)$ & $12(18.8)$ & 10.438 & 0.116 & 0.287 \\
\hline & & & &
\end{tabular}

Note: * indicates significance at $0.05(\mathrm{p}<0.05)$, \# indicates multiple responses allowed.

Source: Field survey 


\section{Conclusion}

The objective of the study was to assess socio-economic determinants of production and consumption AIVS in Kakuma refugee camp and Kakuma town. From the findings it was established that the main AIVs produced and consumed in Kakuma refugee camp were Amaranths, Cowpea, Jute mallow, Okra, Cassava leaves, Black Night shade, and potato leaves while in Kakuma town and its environs were Jute mallow, Amaranths, Cowpea, Okra, Potato leaves, Black Night shade and Cassava leaves. It was evident that Amaranths, Cowpea and Jute mallow were the three commonly grown AIVs in the two regions.

The country of origin, Marital Status and age of the household head were found to significantly influence production of AIVs. Further the study revealed that land ownership among the respondents, communal farming done by self-help groups, creation of awareness by self-help groups and preferences of AIVs to exotic vegetables had a significant relationship with production and consumption of AIVs. Income generation was also revealed as a factor as most of the respondents produced and consumed AIVs because of the financial benefit of AIVs. Cultivation of AIVs in home countries with exception of Ethiopia and Uganda, was found to have no significant relationship with production and consumption of AIVs.

\section{Recommendations}

With reference to the research objective and findings of the study the following recommendations are made, First since age and the country of origin were found to be key factors influencing production and consumption of AIVs, the study recommends that there is need to sensitize people to adopt a culture of producing and consuming more AIVs especially in Arid and Semi-Arid areas such as Kakuma where food insecurity and malnutrition is common. In addition, policymakers need to put aside resources that will help to facilitate production of AIVs in areas that are food insecure.

\section{Acknowledgement}

We thank Hortinlea organization for funding this study. We also thank the anonymous reviewers for their constructive comments that helped shape this paper.

\section{Conflict of interest}

The authors declare that they have no competing interests. All the opinions expressed in this paper are those of the authors and do not reflect the views of the funding agency. 


\section{REFERENCES}

AAH (Action Africa Help International) (2018). Refugees benefit from farming of vegetables.https://www.actionafricahelp.org/refugees-benefit-from-farming-of-traditional-vegetables/Accessed $14^{\text {th }}$ September, 2019.

Abukutsa-Onyango, M. O. (2002, August). Market survey on African indigenous vegetables in western Kenya.In Proceedings of the second horticultural seminar on sustainable horticultural production in the tropics.Jomo Kenyatta University of Agriculture and Technology (JKUAT) (pp. 39-46).

Abukutsa-Onyango, M. O., Adipala, E., Tusiime, G., \& Majaliwa, J. G. M. (2010, September). Strategic repositioning of African indigenous vegetables in the Horticulture Sector. In Second RUFORUM biennial regional conference on "Building capacity for food security in Africa", Entebbe, Uganda (pp. 1413-1419).

Abukutsa-Onyango, M. O., Mwai, G. N., Otiato, D. A., \&Onyango, J. C. (2007). IndigenoVeg Kenya country report: Draft 2. Unpublished IndigenoVeg Survey Report.

Asfaw, Z. (1997). Conservation and use of traditional vegetables in Ethiopia. In Traditional African vegetables: Proceedings of the IPGRI International Workshop on genetic resources of traditional vegetables in Africa Conservation and use. ICRAF-HQ, Nairobi, Kenya (pp. 57-65).

Bua, B., \& Onang, C. (2017). Validating the role of African indigenous vegetables for food and nutrition security in Uganda. $J$ Food Sci Eng, 7, 316-322.

Das, S. (2016). Amaranths: the crop of great prospect. In Amaranthus: A Promising Crop of Future (pp. 13-48). Springer, Singapore.

Feeny, P. (1976). Plant apparency and chemical defense. In Biochemical interaction between plants and insects (pp. 1-40).Springer, Boston, MA.

Gido, E. O., Ayuya, O. I., Owuor, G., \& Bokelmann, W. (2017). Consumption intensity of leafy African indigenous vegetables: towards enhancing nutritional security in rural and urban dwellers in Kenya. Agricultural and Food Economics, 5(1), 116.

Gido, E. O., Ayuya, O. I., Owuor, G., \&Bokelmann, W. (2017). Consumer acceptance of leafy African indigenous vegetables: comparison between rural and urban dwellers. International Journal of Vegetable Science, 23(4), 346-361.

Gido, E. O., Bett, H. K., \&Bokelmann, W. (2016).Importance of African indigenous vegetables in food systems. African Journal of Horticultural Science, 10, 7-7.

Grubben, G. J. H., \& Denton, O. A. (2004). Plant Resources of Tropical Africa 2. Vegetables. PROTA Foundation, Wageningen, Netherlands. backhuys Publishers, Leiden, Netherlands/CTA, Wgeningen Netherlands. Http://www/hort. purdueledu/newcrop. duke_energy/moringa, htm. Accessed on, 4(05), 2008.

Kebede, S. W., \&Bokelmann, W. (2017). African indigenous vegetables and their production practices: evidence from the HORTINLEA survey in Kenya. Agrotechnology, 6(170), 2.

Kimambo, J. J (2016). Analysis of Factors Influencing Producers, Traders and Consumers' Intake of Traditional African Vegetables: The Case Study of Arusha Region, Tanzania (Masters Dissertation, JKUAT).

Kimambo, J. J., Kavoi, M. M., Macharia, J., \&Nenguwo, N. (2018). Assessment of factors influencing farmers' nutrition knowledge and intake of traditional African vegetables in Tanzania. African Journal of Food, Agriculture, Nutrition and Development, $18(2), 13353-13371$.

Kimiywe, J., Waudo, J., Mbithe, D., \&Maundu, P. (2007). Utilization and medicinal value of indigenous leafy vegetables consumed in urban and peri-urban Nairobi. African Journal of Food, Agriculture, Nutrition and Development, 7(4), 1-15.

Maughan, P. J., Smith, S. M., Fairbanks, D. J., \&Jellen, E. N. (2011).Development, characterization, and linkage mapping of single nucleotide polymorphisms in the grain amaranths (Amaranthus sp.).The Plant Genome, 4(1), 92-101.

Maundu, M. P., Ngugi, W. G., \&Kabuye, H. S. C. (1999). Traditional food plants of Kenya. National Museums of Kenya.

www.scirj.org

(C) 2021, Scientific Research Journal

http://dx.doi.org/10.31364/SCIRJ/v9.i06.2021.P0621863

This publication is licensed under Creative Commons Attribution CC BY. 
Mbugua, G. W., Gitonga, L., Ndungu, B., Gatambia, E., Manyeki, L., \&Karoga, J. (2009, August).African indigenous vegetables and farmer-preferences in Central Kenya. In I All Africa Horticultural Congress 911 (pp. 479-485).

Muhanji G, Roothaert RL, WeboC\&Mwangi S (2011) African indigenous vegetable enterprises and market access for small-scale farmers in East Africa. International Journal of Agricultural Sustainability. 9(1):194-202

Mulaudzi, V. S., Oyekale, A. S., \&Ndou, P. (2019).Technical Efficiency of African Indigenous Vegetable Production in Vhembe District of Limpopo Province, South Africa.Open Agriculture, 4(1), 778-786.

Namutebi, A., Akundabweni, L. S. M., Munialo, S., Ssozi, J., Akunadabweni, L. S. M., Mburu, J., \& Tenders, R. U. F. O. R. U. M. (2010). Conserve and screen premium value indigenous plant biodiversity and products on smallholder farming systems of Lake Victoria Basin in East Africa.

Ndegwa, R. (2016). Socio-economic factors influencing smallholder pumpkin production, consumption and marketing in eastern and central Kenya regions (Doctoral dissertation, Kenyatta University).

Ngugi IK, Gitau R, Nyoro J. K (2007). Access to high value markets by smallholder farmers of African indigenous vegetables in Kenya. Regoverning markets innovative practice series, IIED, London.

Oluoch, M. O., Pichop, G. N., Silué, D., Abukutsa-Onyango, M. O., Diouf, M., \& Shackleton, C. M. (2009). Production and harvesting systems for African indigenous vegetables. In African indigenous vegetables in urban agriculture (pp. 177208). Routledge.

Opiyo, A. M., Mungai, N. W., Nakhone, L. W., \&Lagat, K. (2015). Production, status and impact of traditional leafy vegetables in household food security: a case study of Bondo district-Siaya county-Kenya. Advanced Practice Registered Nurse Journal of Agricultural and Biological Science 10(9), 330-338.

Orodho, A. J., \& Kombo, D. K. (2002). Research Methods: Kenyatta University. Institute of Open Learning, Nairobi Kenya.

Priya, V. P., Celine, V. A., Gokulapalan, C., \& Rajamony, L. (2007).Screening amaranth genotypes (" Amaranthus" spp.) for yield and resistance to leaf blight caused by" Rhizoctoniasolani" Kuhn. Plant Genetic Resources Newsletter= Bulletin de Ressources Phytogénétiques= Noticiario de RecursosFitogenéticos, (149), 1-4.

Rubaihayo, E. B. (2002). The contribution of indigenous vegetables to household security. IK Notes, No. 44.

Schippers, R. R. (2002). African indigenous vegetables: an overview of the cultivated species 2002.Aylesford (United Kingdom) DFID/CPIIP/NR

Shackleton, C., Paumgarten, F., Mthembu, T., Ernst, L., Pasquini, M., \& Pichop, G. (2010). Production of and trade in African indigenous vegetables in the urban and peri-urban areas of Durban, South Africa. Development Southern Africa, 27(3), 291-308.

Stoilova, T., Dinssa, F. F., Ebert, A. W., \& Tenkouano, A. (2014, August). The diversity of African leafy vegetables: Agromorphological characterization of subsets of AVRDC's germplasm collection. In XXIX International Horticultural Congress on Horticulture: Sustaining Lives, Livelihoods and Landscapes (IHC2014): 1102 (pp. 67-74).

Tabuti, J. R. S., Dhillion, S. S., \& Lye, K. A. (2004). The status of wild food plants in Bulamogi County, Uganda. International Journal of Food Sciences and Nutrition, 55(6), 485-498.

Turkana County Integrated Development plan 2018-2022.pdf. Accessed on $20^{\text {th }}$ July, 2020 from https://www.google.com/search?client=firefox-b-d\&q=turkana+CIDP+2018-2022

Vorster, H. J., \& Jansen Van Rensburg, W. S. (2005). Traditional vegetables as a source of food in South Africa: Some experiences. In African crop science conference proceedings (Vol. 7, No. pt. 2 of 3, pp. 669-671).

Vorster, I. H. J., Jansen van Rensburg, W. S., \& Venter, S. L. (2007). The importance of traditional leafy vegetables in South Africa. African Journal of Food Agriculture Nutrition and Development, 7(4), 1-13.

Wemali, E. N. C. (2014). Contribution of cultivated African indigenous vegetables to agro biodiversity conservation and community livelihood in Mumias sugar belt, Kenya. Unpublished PhD Theses, Kenyatta University. Kenya. 
Yuan, B., Byrnes, D., Giurleo, D., Villani, T., Simon, J. E., \& Wu, Q. (2018). Rapid screening of toxic glycoalkaloids and micronutrients in edible nightshades (Solanum spp.). Journal of Food and Drug Analysis, 26(2), 751-760. 